Hossain, M.I., M. Khatun, B.M.M. Kamal, K.A. Habib, A.S.Tumpa, B.R. Subba, M.Y. Hossain 2014. Effects of seasonal variation on growth performance of mirror carp (Cyprinus carpio Ver. Specularis) in earthen nursery ponds. Our Nature. 12(1): 8-18. DOI: http://dx.doi.org/10.3126/on.v12i1.12252

\title{
Effects of Seasonal variation on Growth Performance of Mirror carp (Cyprinus carpio Ver. specularis) in Earthen Nursery Ponds
}

\author{
Md. Istiaque Hossain ${ }^{1}$, Murshida Khatun ${ }^{1}$, B.M. Mostafa Kamal ${ }^{2}$, Kazi Ahsan Habib ${ }^{3}$, \\ Ananna Sen Tumpa ${ }^{1}$, Bharat Raj Subba ${ }^{4}$, Md. Yeamin Hossain ${ }^{1}$

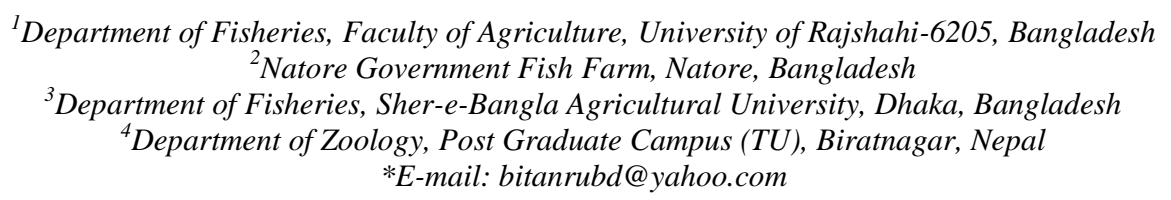

Received: 19.04.2014; Accepted: 24.11.2014

\begin{abstract}
The experiment was conducted to determine the effect of seasonal variation on growth performance of Cyprinus carpio fry in six earthen ponds during December 2011 to June 2012 covering winter (WS) and summer season (SS). Stocking density was 6250 per decimal with a mean weight of $0.192 \pm 0.002(\mathrm{~g})$. This study was done with three replications for each season. During the WS, the mean values of water parameters were temperature $16.78 \pm 2.17$, transparency $32.67 \pm 1.9 \mathrm{~cm}$, dissolved oxygen $5.88 \pm 2.18 \mathrm{mg} / \mathrm{l}$, pH $8.24 \pm 0.49$, total alkalinity $184.72 \pm 22.72$, and ammonia nitrogen $0.21 \pm 0.05$ whereas the mean value of water parameters in SS were temperature $30.56 \pm 1.51$, transparency $30.61 \pm 1.71 \mathrm{~cm}$, dissolved oxygen $4.3 \pm 1.37 \mathrm{mg} / \mathrm{l}$, $\mathrm{pH} 8.33 \pm 0.24$, total alkalinity $274.95 \pm 6.73 \mathrm{mg} / \mathrm{l}$, and ammonia nitrogen $0.16 \pm 0.05 \mathrm{mg} / \mathrm{l}$. Mean values of survival and specific growth rates were $58.94 \pm 0.95$ and $2.45 \pm 0.03$ in WS and $67.85 \pm 4.27$ and $4.00 \pm 1.03$, in SS respectively. Mean gross and net productions in WS were $1581.94 \pm 71.55 \mathrm{~kg} \mathrm{ha}^{-1} 60 \mathrm{~d}^{-1}$ and $1285.03 \pm 69.84 \mathrm{~kg} \mathrm{ha}^{-1} 60 \mathrm{~d}^{-1}$ and, $4262.74 \pm 147.81 \mathrm{~kg} \mathrm{ha}^{-1} 60$ $\mathrm{d}^{-1}$ and $3964.74 \pm 145.74 \mathrm{~kg}$ ha- $160 \mathrm{~d}^{-1}$, in SS respectively. Therefore, it can be concluded that mirror carp fry production was better in SS than in WS.
\end{abstract}

Key words: Seasonal variation, Growth performance, Cyprinus carpio, Water quality parameter

\section{Introduction}

Being cold-blooded animal, fish is affected by the temperature of the surrounding water which influences the body temperature, growth rate, food consumption, feed conversion and other body functions (Houlihan et al., 1993; Britz et al., 1997; Azevedo et al., 1998; Kausar and Salim, 2006). Therefore, water temperature is a driving force in the fish life because its effects are more than any other single factor. Growth and livability in fishes are optimum within a defined temperature range (Gadowaski and
Caddell, 1991; Begum et al., 2003). Although short-term changes, such as weather conditions, may influence a fish for a day or two, but temperature has more predictable and seasonal effect.

Each fish species has an ideal temperature range within which it grows quickly. However, fish move into more favorable areas of a steam to regulate their body temperature. In warmer environment fish have a longer growing season and faster growth rate but tend to have a shorter life 
Md. Istiaque Hossain, Murshida Khatun, B.M. Mostafa Kamal, Kazi Ahsan Habib, Ananna Sen Tumpa, Bharat Raj Subba, Md. Yeamin Hossain / Our Nature (2014), 12(1): 8-18.

span than in cool water. High water temperature increases the metabolic rate, resulting in increased food demand (Begum et al., 2007; Hossain et al., 2013a). Although, fish can generally function in a wide range of temperature, but they do have an optimum range, as well as lower and upper lethal temperature, for various activities (Beschta et al., 1987).

Freshwater fish have an optimum growing temperature in the range of 25$30^{\circ} \mathrm{C}$ (El-Shebly et al., 2007; Shah et al., 2008; Hossain et al., 2013b) at which they grow quickly. During winter, temperature falls, thus influencing biological functions in fish. Mirror carp is an important freshwater fish cultured in Asia, particularly in Bangladesh, India and Pakistan. Therefore, growth rate of this fish and other cultured freshwater carps decreased during the low water temperature period.

Keeping in view the information given above, it can be envisaged that by understanding how temperature affects the performance of fish, particularly during winter season, a farmer can maximize his profit by exploiting maximum production potential of local fish species. However, information regarding the effect of water temperature on various species of fish in Bangladesh is limited. Therefore, an experiment was designed to investigate the effect of seasonal variation (especially changing water temperature during winter and summer) on the growth performance of Mirror carp fry.

\section{Materials and methods}

Study area and experimental design

The research was carried out for a total period of 6 months ( 3 months in winter and
3 months in summer) from December, 2011 to June, 2012 in six nursery ponds located at Banbelgharia, the Government fish seed production farm, Natore Sadar Upazila under Natore district, Bangladesh. The ponds were rectangular in shape and the surface area of each pond was 0.15 hectare (38 decimal) with an average depth of 1.07 meter. Each pond had inlet for watering but no outlet, freed from aquatic vegetation, well-exposed to sunlight and sandy loam bottom soil types. Stocking density of mirror carp fry was $1543750 /$ ha both in winter and summer season.

Pond preparation, stocking and fertilization

Before starting the experiment the ponds were dried and freed from aquatic vegetation. After drying, liming $(\mathrm{CaO})$ was done in all the ponds at the rate of 1 $\mathrm{kg} /$ decimal. Ponds were then filled with ground water at a depth of about 1.07 meter. Seven days after liming, Urea and triple super phosphate (TSP) were applied at the rate of $100 \mathrm{~g} /$ decimal each as basal dose. Seven days after fertilization, Sumithion was applied in all the ponds at the rate 100 $\mathrm{ml} /$ decimal after watering. Fry of Cyprinus carpio var. specularis were stocked in the ponds both in winter and summer season at the density of $6250 \mathrm{fish} /$ decimal after 7 days of fertilization.

\section{Fertilization}

Fertilization of the ponds in winter and summer seasons was done with Urea (200 $\mathrm{gm} /$ decimal) and TSP (100 gm/ decimal) at fortnightly basis. TSP was dissolved in water for 24 hours before and Urea was dissolved in a bucket in the morning and 
Md. Istiaque Hossain, Murshida Khatun, B.M. Mostafa Kamal, Kazi Ahsan Habib, Ananna Sen Tumpa, Bharat Raj Subba, Md. Yeamin Hossain / Our Nature (2014), 12(1): 8-18.

then applied by spreading with a mug on the pond surface. Fertilization was done fortnightly.

\section{Supplementary feeding}

The fish was fed with a mixture of rice bran $(50 \%)$, mustard oil $(30 \%)$ cake and wheat bran $(20 \%)$ at the rate of $50 \%$ of their body weight from day 1 to 90 .

\section{Study of water quality parameters}

The physico-chemical parameters of pond water were recorded fortnightly throughout the experimental period between 10 A.M. and 12 A.M. Physical parameters such as; water temperature $\left({ }^{\circ} \mathrm{C}\right)$, transparency $(\mathrm{cm})$, and water depth $(\mathrm{m})$ were measured at the pond site on each sampling day. Depth of water of the experimental ponds was estimated with the help of a graduated wooden scale. Water transparency of the experimental ponds was measured by a Secchi-disk, it was immersed into the water and then the visible and invisible depths under the water to the naked eye were measured in $\mathrm{cm}$. water temperature was recorded with a Celsius thermometer at 15$20 \mathrm{~cm}$ depth. The dissolved oxygen concentration of water was determined by the aid of a water quality test kit (HACH kit model FF-2, made in USA). The negative logarithm of the hydrogen ion concentration or $\mathrm{pH}$ of water was measured by using HACH kit (model FF-2, cat. No. 2430-01, made in USA) and total alkalinity of water sample was determined by titrimetric method using methyl orange indicator. Ammonia-Nitrogen was measured by using a HACH kit (model FF-2, cat. No. 2430-01, made in USA). Rochelle salt solution and Nessler reagent were used to measure the
$\mathrm{NH}_{3}-\mathrm{N}$. A colour comparator (value ranging from 0 to $3.0 \mathrm{mg} / \mathrm{I}$ ) also used for the same.

\section{Harvesting of fish}

At the end of the experiment the water of the ponds were pumped out and all the fishes were harvested. The growth of fish was recorded by measuring the length $(\mathrm{cm})$ and weight $(\mathrm{g})$ of the harvested fishes by using a measuring scale and a balance respectively.

\section{Estimation of survival rate, growth and production of fish}

(i) The survival rate was estimated by the following formula:

Survival Rate $(\%)=\frac{\text { No. of harvested fishes }}{\text { Initial no. of fishes }} \times 100$

\section{Fish production}

At the end of the experiment, all fish were harvested and following parameters were used to determine production of fishes in different seasons.

\section{Individual stocking weight (g)}

Individual fish weight was taken using electric balance as gram (g) during stocking.

\section{Individual final weight (g)}

It was taken at the time of harvest and was expressed as gram (g).

\section{Weight gain (g)}

(i) The weight gain was calculated through the following equation-

Weight gain $(\mathrm{g})=$ Mean final weight $(\mathrm{g})$ Mean initial weight $(\mathrm{g})$

(ii) Specific growth rate (SGR \%) was estimated by the following formula: 
Md. Istiaque Hossain, Murshida Khatun, B.M. Mostafa Kamal, Kazi Ahsan Habib, Ananna Sen Tumpa, Bharat Raj Subba, Md. Yeamin Hossain / Our Nature (2014), 12(1): 8-18.

$\operatorname{SGR}(\%$ per day $)=$

$\frac{\text { In (final weight) }- \text { In (initial weight) }}{\text { Culture period (days) }} \times 100$

(iii) Calculation of gross fish production (ton/ha/yr):

Gross fish production $=$

$\frac{\text { Gross weight }(\mathrm{kg}) \text { of fish per decimal per month }}{1000} \times 247 \times 12$

(iv) Calculation of net fish production (ton/ha/yr)

Net fish production $=\frac{\text { Net weight }(\mathrm{kg}) \text { of fish per decimal per month }}{1000} \times 247 \times 12$

\section{Statistical analysis}

All data were analyzed using GraphPad Prism 5 statistical software (GraphPad Software, Inc., San Diego, CA) after they were checked for normal distribution and homogeneity of variance. Tests for normality of each group were conducted by visual assessment of histograms, box plots and confirmed using the KolmogorovSmirnov test. Only percent data had to be arcsine transformed before analysis; however, non- transformed data are presented in tables. Where the normality assumption was not met, the non-parametric Mann-Whitney U-test was used to check the effects on weight gain, survival, growth and production between WS and SS. All statistical analyses were considered significant at $5 \%(\mathrm{p}<0.05)$.

\section{Results and discussion}

\section{Physical parameters and Chemical parameters}

The mean values of water depth of the ponds in winter and summer were $0.90 \pm 0.03 \mathrm{~m}$ and $0.88 \pm 0.02 \mathrm{~m}$ respectively (Table 1). Water depth has great influence on the productivity of a water body. In shallow water bodies sunlight penetrates up to the bottom and thus increases the productivity. During the experimental period, fortnightly fluctuations of water depth ranged form 0.79 to $0.99 \mathrm{~m}$. Jhingran (1975) stated that a depth of about $2 \mathrm{~m}$ of a pond is suitable from the biological point of productivity. Rahman (1992) and Hossain et al. (2001) stated that pond should not be shallower than $1 \mathrm{~m}$ and deeper than $5 \mathrm{~m}$ and optimum depth should be $2 \mathrm{~m}$.

The mean values of water transparency, dissolved oxygen (DO), $\mathrm{pH}$, total alkalinity and ammonia-nitrogen of the ponds in winter were $32.67 \pm 1.9 \mathrm{~cm}$, $5.88 \pm 2.18 \mathrm{mg} / \mathrm{l}, \quad 8.24 \pm 0.49, \quad 184.72 \pm 22.72$ $\mathrm{mg} / \mathrm{l}, 0.21 \pm 0.05 \mathrm{mg} / \mathrm{l}$, whereas, the above parameters in summer were $30.61 \pm 1.71 \mathrm{~cm}$, $4.3 \pm 1.37 \mathrm{mg} / 1,8.33 \pm 0.24,274.95 \pm 6.73 \mathrm{mg} / \mathrm{l}$ and $0.16 \pm 0.05 \mathrm{mg} / \mathrm{l}$, respectively (Table 1 ). Azam (1996), Nahar (1997), Kawser (1998), Tasneem (1998), Rashid (1999), Israfil (2000), Kabir (2003), Khatun (2004), Chowdhury (2005), Uddin (2005) and Hossain et. al. (2007) recorded almost similar transparency, DO and $\mathrm{pH}$ values of 
Md. Istiaque Hossain, Murshida Khatun, B.M. Mostafa Kamal, Kazi Ahsan Habib, Ananna Sen Tumpa, Bharat Raj Subba, Md. Yeamin Hossain / Our Nature (2014), 12(1): 8-18.

pond water in similar experiments. Fortnightly variations of water transparency during the experimental period ranged from 27.00 to $38.00 \mathrm{~cm}$. Rahman (1992) stated that the transparency of productive waterbodies should be $40 \mathrm{~cm}$ or less (turbidity resulting from plankton). Kohinoor (2000) recorded transparency values ranging from 15 to $58 \mathrm{~cm}$. According to Kamal et al. (2012) transparency fluctuated between 19 $\mathrm{cm}$ and $49 \mathrm{~cm}$ in the seasonal ponds at Natore, Bangladesh. Dissolved oxygen content of the ponds were found between 2.75 to $8.9 \mathrm{mg} / \mathrm{l}$. Hossain (2012) found the DO content ranged from 4.8-8.7 ppm.

Kamal et al. (2012) recorded DO content varried from $1.80 \mathrm{mg} / 1$ to $9.8 \mathrm{mg} / \mathrm{l}$ in the seasonal ponds of Natore, Bangladesh. Banerjea (1967) stated that 5-7 ppm of dissolved oxygen of a water body is good for biological productivity. The fluctuations of $\mathrm{pH}$ values during the experimental period in winter and summer ranged from 7.0 to 9.0 and 8.0 to 9.0 respectively. According to Swingle (1967) and Hossain et al. (2006), pH 6.5 to 9.0 is suitable for pond fish culture and $\mathrm{pH}$ more than 9.5 is unsuitable because free $\mathrm{CO}_{2}$ is not available in this situation. Kamal et al. (2012) found the $\mathrm{pH}$ values ranged from 6.88 to 9.22 at the seasonal ponds of Natore, Bangladesh. Fortnightly fluctuations of total alkalinity in the experimental ponds ranged from 128.00 to $188.00 \mathrm{mg} / \mathrm{l}$. Mairs (1966) stated that water bodies having total alkalinity $40 \mathrm{mg} / \mathrm{l}$ or more are considered more productive than the water bodies of lower alkalinity. Fortnightly fluctuations of ammonia-nitrogen in the experimental ponds ranged from 0.1 to $0.3 \mathrm{mg} / \mathrm{l}$. Wahab et al. (1995), Kadir et al. (2007) and
Milstein et al., (2009) recorded ammonianitrogen $\left(\mathrm{NH}_{3}-\mathrm{N}\right)$ of 0.09 to $0.99 \mathrm{mg} / 1,0.11$ to $0.52 \mathrm{mg} / \mathrm{l}$ and 0.6 to $0.29 \mathrm{mg} / \mathrm{l}$, respectively.

The highest water temperature recorded was $35^{\circ} \mathrm{C}$ found in summer and the lowest water temperature was recorded $14^{\circ} \mathrm{C}$ in winter. The mean values of water temperature of the ponds in winter and summer were $16.78 \pm 2.17$ and $30.56 \pm 1.51^{\circ} \mathrm{C}$, respectively (Table 1). Houlihan et al. (1993), Britz et al. (1997) and Azevedo et al. (1998) observed that fish were markedly influenced by the water temperature in which they lived. However, different fish require different temperature regimes; a range between $25-30^{\circ} \mathrm{C}$ is being optimum for Mirror carp. The lower body weight gain of the mirror carp in low water temperature $\left(20-22^{\circ} \mathrm{C}\right)$ may be due to less feed intake than those in higher water temperature (24$26^{\circ} \mathrm{C}$ ). Jauncey and Ross (1982) have reported that most species cease to feed at low temperatures (below $16^{\circ} \mathrm{C}$ ). Therefore, better growth rate at $26-35^{\circ} \mathrm{C}$ in Mirror carp may be attributed to the high water temperature, which increased feed intake and metabolic rate of the fish. Similar results were obtained by Kumar et al. (2000), Zaman et al. (2002), Frei and Becker (2005), Kauser and Salim (2006), Hossain (2012), Hossain et al. (2013). Kamal et al. (2012) recorded water temperature ranged from $25.5^{\circ} \mathrm{C}$ to $32.6^{\circ} \mathrm{C}$ in the seasonal ponds at Natore, Bangladesh.

\section{Growth and production performances of mirror carp}

The mean individual stocking wt $(\mathrm{g})$ of mirror carp was $0.192 \pm 0.002$ and 
Md. Istiaque Hossain, Murshida Khatun, B.M. Mostafa Kamal, Kazi Ahsan Habib, Ananna Sen Tumpa, Bharat Raj Subba, Md. Yeamin Hossain / Our Nature (2014), 12(1): 8-18.

Table 1 Physico-chemical characters of water in the earthen ponds during the winter and summer season.

\begin{tabular}{lllc}
\hline \multicolumn{1}{c}{ Parameters } & Winter & Summer & $\begin{array}{c}\text { Level of } \\
\text { Significance }\end{array}$ \\
\hline Water depth $(\mathrm{m})$ & $0.90 \pm 0.03$ & $0.88 \pm 0.02$ & $\mathrm{NS}$ \\
Transparency $(\mathrm{cm})$ & $32.67 \pm 1.9$ & $30.61 \pm 1.71$ & $\mathrm{NS}$ \\
Water temperature & $16.78 \pm 2.17$ & $30.56 \pm 1.51$ & $\mathrm{NS}$ \\
Dissolved oxygen (mg/L) & $5.88 \pm 2.18$ & $4.3 \pm 1.37$ & $\mathrm{NS}$ \\
$\mathrm{pH}$ & $8.24 \pm 0.49$ & $8.33 \pm 0.24$ & $\mathrm{NS}$ \\
Total Alkalinity(mg/L) & $184.72 \pm 22.72$ & $274.95 \pm 6.73$ & $\mathrm{NS}$ \\
$\mathrm{NH}_{3}-\mathrm{N}(\mathrm{mg} / \mathrm{L})$ & $0.21 \pm 0.05$ & $0.16 \pm 0.05$ & $\mathrm{NS}$ \\
\hline
\end{tabular}

NS: Not significant

Table 2 Growth performance of Cyprinus carpio during winter and summer season in the earthen ponds.

\begin{tabular}{lllll}
\hline \multirow{2}{*}{ Parameters } & \multicolumn{2}{l}{ Winter } & \multicolumn{2}{c}{ Summer } \\
\cline { 2 - 5 } & Mean & SD & Mean & SD \\
\hline Mean individual stoking wt. (g) & 0.192 & 0.002 & 0.193 & 0.001 \\
Survival (\%) & 58.94 & 0.949 & 67.85 & 4.27 \\
Mean individual harvesting wt. (g) & 1.74 & 0.060 & 4.08 & 0.12 \\
SGR (\% bw d ${ }^{-1}$ ) & 2.45 & 0.030 & 4.00 & 1.03 \\
Gross production $\left(\mathrm{kg} \mathrm{ha}^{-1} 60 \mathrm{~d}-1\right)$ & 1581.94 & 71.551 & 4262.74 & 147.81 \\
Net production $\left(\mathrm{kg} \mathrm{ha}^{-1} 60 \mathrm{~d}-1\right)$ & 1285.03 & 69.836 & 3964.74 & 145.74 \\
\hline SD: standard devition & & & &
\end{tabular}

SD: standard deviation

$0.193 \pm 0.001$ in winter and in summer, respectively. Mirror carp reached mean individual harvesting weight of $1.74 \pm 0.06$ and $4.08 \pm 0.12$ in winter and in summer, respectively. The survival rates of mirror carp was $58.94 \pm 0.95$ and $67.85 \pm 4.27$ in winter and in summer, respectively. The gross production of mirror carp was $1581.94 \pm 71.55 \quad \mathrm{~kg} \quad \mathrm{ha}^{-1} \quad 60 \mathrm{~d}^{-1}$ and $4262.74 \pm 147.81 \mathrm{~kg} \mathrm{ha}^{-1} 60 \mathrm{~d}^{-1}$ in winter and in summer, respectively. The net production of mirror carp was $1285.03 \pm 69.84 \mathrm{~kg} \mathrm{ha}^{-1}$ $60 \mathrm{~d}^{-1}$ and $3964.74 \pm 145.74 \mathrm{~kg} \mathrm{ha}^{-1} 60 \mathrm{~d}^{-1}$ in winter and in summer, respectively.
However, it was found that the gross and net production of mirror carp in summer was better than in winter, which was $4262.74 \pm 147.81 \quad \mathrm{~kg} \quad \mathrm{ha}^{-1} \quad 60 \mathrm{~d}^{-1}$ and $3964.74 \pm 145.74 \mathrm{~kg} \mathrm{ha}^{-1} 60 \mathrm{~d}^{-1}$ (Table 2).

During the WS, the growth was almost similar in all the three replications. ANOVA revealed that the body weight among three replications were not significantly difference $(\mathrm{P}=0.702)$. However, in summer season, the significantly difference $(\mathrm{P}=0.761)$ among the three replications was observed. Mann-Whitney U-test indicated that the growth in summer (Median $=3.78 \mathrm{~g}$ ) 
Md. Istiaque Hossain, Murshida Khatun, B.M. Mostafa Kamal, Kazi Ahsan Habib, Ananna Sen Tumpa, Bharat Raj Subba, Md. Yeamin Hossain / Our Nature (2014), 12(1): 8-18.

was significantly higher than in winter (Median=1.78g) (Two tailed, MannWhitney $\mathrm{U}=3.00, \mathrm{P}<0.001)$

\section{Survival rate, growth and producti fish}

\section{Survival rate $(\%)$}

In the present experiment, the survival rates were different in different experimental ponds. The survival rate of mirror carp was $58.94 \pm 0.95$ and $67.85 \pm 4.27$ in winter and in summer, respectively (Table 2). Malecha et al. (1981) conducted a feasibility study of raising freshwater prawn (M. rosenbergii) without supplemental feed in a culture system. Of the two ponds, one received fresh manure from swine and was stocked with silver carp, big head carp, grass carp, common carp (later) at the ratio of 65:1:4:12 and with prawn at the density of $7.9 / \mathrm{m}^{2}$ and the other received only effluent, was stocked with silver carp, bighead carp, grass carp, at a density of $650,79,10-15 / \mathrm{ha}$ and with prawn at $4.6 / \mathrm{m}^{2}$. They found that the gained averaged fish biomass of 14.38 $\mathrm{kg} / \mathrm{ha} /$ day with the manure pond and 6.06 $\mathrm{kg} / \mathrm{ha} /$ day with the effluent pond and gained averaged prawn biomass of $2.46 \mathrm{~kg} / \mathrm{ha} /$ day. The study also showed that the survivi $17.4 \%$ to $48.1 \%$ with the manure and effluent ponds, respectively. In the present study, the survival rate was low because mirror carp spawn was released. In case of spawn, mortality rate was high due to the environmental factors, water quality parameters, food competition and was stocked together with high stocking rates, although the experimental ponds were prepared effectively with appropriate doses of lime, urea and TSP. Haque (2005) recorded the survival rates of $89.50 \%$ and $90 \%$ in winter and in summer season respectively in monoculture of Thai sharpunti (Puntius gonionotm). Jannat et al. (2012) obtained survival rates of 92 to $94 \%$ in monoculture of Thai climbing perch.

\section{Specific growth rate (SGR\% per day)}

In the present study, the specific growth rates of mirror carp was $2.45 \pm 0.03$ and $4.00 \pm 1.03$ in winter and in summer (Table 2). Hossain and Islam (2006), reported the SGR of prawn, catla, rohu and silver carp ranged from 3.99 to $4.26,3.71$ to $3.83,2.49$ to 2.55 and 2.44 to $2.59 \%$ respectively. The specific growth rate in summer season was higher because the environment is suitable for fish. The temperature, water transparency, DO, Alkalinity, Ammonium-ion, Hardness etc. are limiting factors were in suitable ranges. De silva and Davy (1992) stated the SGR of fish was high because of high feed protein and energy diet that showed high value of nutrients. Whereas the supplementary fish feeds was made in farm manually showed the SGR value between 3-4\% per day. Besides this, the fish fry was comparatively small size, of which the growth and production of carps cultured in winter and summer season was not the satisfactory level.

\section{Production of fish}

In the present experiment, calculated gross and net production of fish in winter was $1581.94 \pm 71.55$ and $1285.03 \pm 69.84 \mathrm{~kg} \mathrm{ha}^{-1} 60$ $\mathrm{d}^{-1}$ whereas in summer, gross and net production was $4262.74 \pm 147.81$ and $3964.74 \pm 145.74 \mathrm{~kg} \mathrm{ha}^{-1} 60 \mathrm{~d}^{-1}$ (Table 2). Net production of fish in summer was higher than that of in winter season because the environment was suitable for fish growth. The temperature, water transparency, DO, Alkalinity, Ammonium-ion, Hardness etc. the limiting factors were in suitable ranges. 
Md. Istiaque Hossain, Murshida Khatun, B.M. Mostafa Kamal, Kazi Ahsan Habib, Ananna Sen Tumpa, Bharat Raj Subba, Md. Yeamin Hossain / Our Nature (2014), 12(1): 8-18.

Alim et al. (2005) found their experiment on stocking of carps in polyculture, $20 \%$ large carps stocking did not affect the survival rate and the production of rohu and catla (but not as same as common carp). Hepher et al. (1989) found in an experiment, the effect of fish density and species combination on the growth and utilization of natural food in ponds, the yield of all combined species in the polyculture was higher where at the density of 1300 carps/ha $(2116 \mathrm{~kg} / \mathrm{ha}$ in 156 days). At 2600 carps/ha density reduced the total rate of silver carp growth, as compared with the lower density. Lakshmanan et al. (1968) conducted an experiment to the Preliminary study on the rearing of carp fingerlings. They found that in the experiment the stocking of major carp fries in polyculture under three densities, viz. $62,500,93,750$ and 125,000 per hectare (i.e. 250, 375 and 500 per decimal). The species ratio of Catla catla, Labeo rohita. Cirrhina mrigala and Cyprinus carpio var. commnnis was 3:4:1:2 respectively. The negligible difference in the growth rate of three stocking rates showed that optimum stocking does not mean under stocking. The average production rates under the three densities was ranged from 2002.28 to $3127.75 \mathrm{~kg} / \mathrm{ha} /$ three months, which are considered very encouraging. The fish population densities of the present experiment were very high. Lorenzen (2001) carried out an experiment entitled "Using population models to assess culturebased fisheries: a brief review with an application to the analysis of stocking experiments" he found that population dynamics models are powerful tools for the analysis of culture-based fisheries, optimization of stocking and harvesting regimes. Key population processes and the culture-based fisheries are briefly reviewed, and approaches to the practical assessment of management regimes are outlined. A model was developed for the analysis of stocking experiments, and was applied to mrigal (Cirrhimus mrigala) stocking in Huay Luang reservoir in Thailand. From this experiment it reveals that determination of suitable fish population density is very important in fish culture. Hashim et al. (2002) conducted an experiment on "Production of hybrid red tilapia, Oreochromis mossambicus $\times$ O. niloticus, at varying stocking densities in portable canvas tanks" the stocking rate of $79 \mathrm{fish} / \mathrm{m}^{3}$ resulted in the highest specific growth rate (SGR) and relative growth rate (RGR) but was not significantly different from stocking rates of 119 and $159 \mathrm{fish} / \mathrm{m}^{3}$. However, feed conversion ratio (FCR), condition factor $(\mathrm{CF})$, and survival rate did not differ significantly among all stocking densities. Based on these findings, a maximum stocking rate of $159 \mathrm{fish} / \mathrm{m}^{3}$ is recommended for culture of tilapia. The five stocking densities of tilapia were 79,119 , 159, 198 and 328 fish per $\mathrm{m}^{3}$ in their experiment. Above the 5 stocking densities, $159 \mathrm{fish} / \mathrm{m}^{3}$ was most suitable for the culture system.

\section{Conclusion}

In the present experiment, the specific growth rate $\left(\mathrm{SGR} \% \mathrm{bwd}^{-1}\right)$ and the production of mirror carp fries was recorded comparatively better in summer than that of winter season while the stocking density and size of mirror carp fries were same. During this period almost all the physicochemical parameters of the experimental ponds water were found more 
Md. Istiaque Hossain, Murshida Khatun, B.M. Mostafa Kamal, Kazi Ahsan Habib, Ananna Sen Tumpa, Bharat Raj Subba, Md. Yeamin Hossain / Our Nature (2014), 12(1): 8-18.

or less similar at summer and winter season but it was big differ in temperature. Though the stocking density and size of mirror carp fries were same but the production of fishes was recorded higher in summer season where the temperature was better than in winter. It can be concluded that the ranges of water temperature from $26-35^{\circ} \mathrm{C}$ seemed to be the most effective for rearing of Mirror carp in Bangladesh. However, the effect of water temperature on nutrient digestibility of the diet fed to the Mirror carps still remains an important factor, which might be played an important role in understanding the growth performance of the fish.

\section{Acknowledgements}

The authors would like to thank the staffs of Natore Government Fish Farm, Natore, Bangladesh for their help during the experiment.

\section{References}

Akhteruzzaman, M., A.H.M. Kohinoor and M.S. Shah 1992. Observations on the induced breeding of Puntius sarana (Ham). Bangladesh Journal of Zoology 20: 291-295.

Alim, M. A. 2005. Developing a polyculture technique for farmers consumption and cash crop. Ph.D. Dissertation, Department of Fisheries Management, Bangladesh Agricultural University, Mymensingh. $192 \mathrm{p}$.

Azam, M.R. 1996. Effects of periphyton on tilapia production. An M.S. thesis submitted to the Department of Fisheries Biology and Limnology, Faculty of Fisheries, BAU, Mymensingh.

Azevedo, P.A., Cho, C.Y., Leeson, S. and Bureau, D.P. 1998. Effects of feeding level and water temperature on growth, nutrient and energy utilization and waste outputs of rainbow trout (Oncorhynchus mykiss). Aquat. Living Resour, 11(4): 227-238. http://dx.doi.org/10.1016/S09907440(98)89005-0

Banerjea, S.M. 1967. Water quality on soil condition of fish ponds in some states of India in relation to fish production. Indian J. Fish., 14:115-144.
Begum, M., Hossain, M.Y., Wahab, M. A., Ahmed, Z. F., Alam, M. J., Shah, M. M. R., Jasmine, S., El-Kady M.A.H.. and Fulanda, B. 2007. Effects of isonutrient fertilization on plankton production in earthen ponds of Bangladesh. Pakistan Journal of Biological Sciences, 10(8): 1221-1228. http://dx.doi.org/10.3923/pjbs.2007.1221.1228

Begum, M., Hossain, M.Y., Wahab, M.A. \& Kohinoor, A.H.M. 2003. Effects of isophosphorus fertilizers on water quality and biological productivity in Fish pond. Journal of Aquaculture in the Tropics, 18(1):1-12.

Beschta, R.L., Bibly, R.E., Brown, G.W., Holtby, L.B., Hofstra, T.D. 1987. Stream temperature and aquatic habitat. In: Salo, E. O., and T. W. Cundy (Eds) Streamside Management: Forestry and Fishery Interactions. University of Washington, Institute of Forest Resources. Contribution No. 57. 191-232.

Britz, P.J., Hecht, T. and Mangold, S. 1997. Effect of temperature on growth, feed consumption and nutritional indices of Haliotis midae fed a formulated diet. Aquaculture, 152: 191-203. http://dx.doi.org/10.1016/S0044-8486(97)00002-1

Chowdhury, M.M.R. 2005. Use of duckweed (Lemna minor) as supplementary feed in monoculture of tilapia (Oreochromis niloticus). M.S. thesis, Deptt. of Fisheries Management, Bangladesh Agricultural University, Mymensingh.

De Silva, S.S. and Davy, F.B. 1992. Fish nutrition research for semi-intensive culture system in Asia. Asian Fish. Sci., 5: 129-144.

El-Shebly, A.A., El-Kady, M.A. \& Hossian, M.Y. 2007. A preliminary Observation of the pond culture of European eel, Anguilla anguilla (Linnaeus, 1758) in Egypt: Recommendations for Future Studies. Pakistan Journal of Biological Sciences, 10(7): 1050-1055.

Frei, M. and Becker, K. 2005. A greenhouse experiment on growth and yield effects in integrated rice-fish culture. Aquaculture. 244: 119-128. http://dx.doi.org/10.1016/j.aquaculture. 2004.11.014

Gadowaski, D.M. and Caddell, S.M. 1991. Effects of temperature on early-life-history stages of California halibut Paralichthys californicus. Fish Bull., 89: 567-576.

Haque, M.S. 2005. Use of duckweed (Lemnct minor) as supplementary feed in monoculture of Sharpunti (Puntius gonionotus). MS thesis, Department of Fisheries Management, 
Md. Istiaque Hossain, Murshida Khatun, B.M. Mostafa Kamal, Kazi Ahsan Habib, Ananna Sen Tumpa, Bharat Raj Subba, Md. Yeamin Hossain / Our Nature (2014), 12(1): 8-18.

Bangladesh Agricultural University, Mymensingh. $87 \mathrm{pp}$.

Hashim, R., Chong, A.S.C., Fatan, A.N.L., Norashikin, and Ali, A. 2002. Production of hybrid red tilapia, Oreochromis mossambicus $\times$ $O$. niloticus, at varying stocking densities in portable canvas tanks. Journal of Applied $\begin{array}{llll}\text { Aquaculture, } & 12 & \text { (3): } & 1-12 .\end{array}$ http://dx.doi.org/10.1300/J028.v12n03_01

Hepher, B.A., Milstein, H., Leventer and Teltsch, B. 1989. The effect of fish density and species combination on growth and utilization of natural food in ponds. Aquaculture and Fisheries Management, 1989, 20: 59-71.

Hossain, M. I., Faruk, M. A. R., Miah, M. J. U., Kanak, M. K. and Roy, N. C. 2001. Effect of fertilization on benthos production, Bangladesh $J$. Fish, 24(1-2): 39-43.

Hossain, M. Y., Begum, M., Ahmed, Z.F., Hoque, M.A., Karim, M.A. and Wahab, M.A. 2006. A Study on the effects of iso-phosphorus fertilizers on plankton production in fish ponds. South Pacific Studies, 26(2):101-110.

Hossain, M.A. and Islam, M.S. 2006. Optimization of stocking density of freshwater prawn (Macrobrachium rosenbergii (de man) in carp polyculture in Bangladesh. Aquaculture Research, 37: 994-1000. http://dx.doi.org/10.1111/j.13652109.2006.01518.x

Hossain M. Y., Jasmine, S., Ibrahim, A.H.M., Ahmed, Z. F., Ohtomi, J., Fulanda, B., Begum, M., Mamun, A., El-Kady, M.A.H. and Wahab, M. A. 2007. A preliminary observation on water quality and plankton of an earthen fish pond in Bangladesh: Recommendations for future studies. Pakistan Journal of Biological Sciences, 10 (6): 868-873. http://dx.doi.org/10.3923/pjbs.2007.868.873

Hossain, M. I. 2012. Effects of fertilization on benthos production, Mymenshing, Bangladesh. Lambert academic publishing, GmbH \& Co KG, Germany. 1-65.

Hossain, M. I., Kamal, M. M., Mannan, M. A., Bhuyain, M. A. B. and Hossain, M. I. 2013a. Effects of Probiotics on Growth and Survival of Shrimp (Penaeus monodon) in Coastal Pond at Khulna, Bangladesh. J. Sci. Res. 5(2), 363-370.

Hossain, M. I., Alam, M. M., Alam, M., Kamal, B. M. M. and Galib, S. M. 2013b. Investigation of Phytoplankton and Physico-chemical Parameters in Nursery, Grow out and Brood stock Ponds. J.
Sci. Res. 5(3): 553-569. http://dx.doi.org/10.3329/ jsr.v5i3.14886

Hossain, M.I., Ahmed, S., Reza, M.S., Hossain, M.Y., Islam, M.N., Jesmine, A. and R. Islam. 2013. Effects of organic fertilizer and supplementary feeds on growth performance of silver carp (Hypophthalmichthys molitrix) and bata (Cirrhinus reba) fry in nursery ponds. International Journal of Research in Applied, Natural and Social Sciences (IJRANSS) 1(2): 117124.

Houlihan, D.F., Mathers, E.M. and Foster, A. 1993. Biochemical correlates of growth rate in fish. In: Fish Ecophysiology. J. C. Rankin and F. B. Jensen (Eds.). Chapman and Hall, London. UK, 45-71. http://dx.doi.org/10.1007/978-94-011-2304-4_2

Israfil, M. 2000. Effects of periphyton on monoculture of Thai Sharputi (Puntius gonionotits). An M.S. thesis submitted to the Department of Fisheries Management, BAU, Mymensingh, Bangladesh.

Jannat, K.M., Rahman, M.M., Bashar, M.A., Hasan, M.N., Ahamed, F. and Hossain, M.Y. 2012. Effect of stocking density on survival, growth and production of Thai climbing Perch (Anabas testudineus) under fed ponds. Sains Malaysiana 41(10): 1205-1210.

Jauncey, K. \& Ross, B. 1982. The effects of varying dietary protein levels on the growth, feed conversion, protein utilization and body composition of juvenile tilapias (Sarotherodon mossambicus). Aquaculture, 27: 43-54. http://dx.doi.org/10.1016/0044-8486(82)90108-9

Jhingran, V.G. 1975. Aquaculture lecture, Summer Int. Intensive fresh water fish culture, Cuttack, Organized by centre. Inland Fish. Res. Jnst, Braackpore (ICAR), India, 12 pp.

Kabir, A.N.M.A. 2003. Use of duckweed (Lemna minor) as feed for fishes in polyculture. M.S. thesis, Deptt. of Fisheries Management, Bangladesh Agricultural University, Mymensingh.

Kadir, A., Wahab, M.A., Miistein, A., Hossain, M.A. \& Seraji, M.T.I. 2007. Effects of silver carp and the small indigenous fish mola, Amblypharyngodon mola and punti, Puntius sophore on fish polyculture production. Aquaculture, $\quad$ 273(4): $\quad 520-531$ http://dx.doi.org/10.1016/j.aquaculture.2007.07.01 2

Kamal, B.M.M., Hossain, M.I., Rahman, M.M., Mannan, M.A. and Sarkar, M.A. 2012. Effects of feeding and fertilization on the growth and 
Md. Istiaque Hossain, Murshida Khatun, B.M. Mostafa Kamal, Kazi Ahsan Habib, Ananna Sen Tumpa, Bharat Raj Subba, Md. Yeamin Hossain / Our Nature (2014), 12(1): 8-18.

production of Puntius sophore in seasonal ponds in Natore, Bangladesh. J. bio-sci. 20: 135-142.

Kausar, R. and Salim, M. 2006. Effect of Water Temperature on the Growth Performance and Feed Conversion Ratio of Labeo Rohita. Pakistan Vet. J., 26(3): 105-108.

Kawser, R. 1998. Effects of periphyton on production of major carps. M.S. thesis, Department of Fisheries Management, Bangladesh Agricultural University, Mymensingh, 1-83.

Khatun, B. 2004. Effects of duckweed (Lemna minor) as supplementary feed on monoculture of tilapia (Oreochromis niloticus). M.S. thesis, Dept. of Fisheries Management, Bangladesh Agricultural University, Mymensingh.

Kohinoor, A.H.M. 2000. Development of culture technology of three small indigenous fish mola (Amblypharyngodon mold\}, punti (Puntius sophore) and chela (Chela cachius) with notes on some aspects of their biology. Ph. D. Dissertation, Department of Fisheries Management, BAU, Mymensingh, 363 pp.

Kohinoor, A.H.M., Akteruzzaman, M. and Shah, M.S. 1993. Red tilapia production potential under low input management in Bangladesh. Paper presented at the Third Fisheries Forum, 26-30 October, World Trade Center, Singapore.

Kumar, A., Pandey, C.K. and Kumar, N. 2000. Effects of polyhouse on growth of common carp at high altitude of Central Himalayas during winter. Journal of Aquaculture. 8: 73-75.

Lakshmanan, M. A. V., P. R. Sen; D. S. Murty and D. P. Chakraborty. 1968. Preliminary study on the rearing of carp finerlings. Indian J. Fish. 15(1\& 2): 40-52.

Lorenzen, K. 2001. Using population models to assess culture-based fisheries: a brief review with an application to the analysis of stocking experiments. Reservior and culture based fisheries: biology and management. Proceedings of an International Workshop held in Bangkok, Thailand, from 15-18 February, 2000, 257-265.

Mairs, D.F. 1966. A total alkalinity atlas for Maine lakes waters. Limnol. Oceanogr. 2: 68-72. http://dx.doi.org/10.4319/lo.1966.11.1.0068

Malecha, S.R., Buch, D.H., Baur, R.J. \& Onizuka, D.R. 1981. Polyculture of freshwater prawn, Macrobrachium rosenbergil, Chinese and common carps in ponds in enriched with swine manure. I. Initial trials. Aquaculture, 25: 101-116. http://dx.doi.org/10.1016/0044-8486(81)90173-3

Milstein, A., Wahab, M.A., Kadir, A., Sagor, M.F.H.
\& Islam, M.A. 2009. Effects of intervention in the water column and/or pond bottom through species composition on poly culture of large carps and small indigenous species. Aquaculture, 286: 246253. http://dx.doi.org/10.1016/j.aquaculture.2008. 09.036

Nahar, S. 1997. Effects of penphyton grown on different substrates on fish production. M.S. thesis, Department of Fisheries Management, B A 11 Mymensingh, Bangladesh.

Rahman, M.S. 1992. Water Quality Management in Aquaculture, BRAC Prokashana, 66, Mohakhali, Dhaka-1212, Bangladesh, 1-84.

Rashid, M.M. 1999. Effects of periphyton on monoculture of Labeo gonius. An M.S. thesis submitted to the Department of Fisheries Management, Bangladesh Agricultural University, Mymensingh, Bangladesh, 1-78.

Shah, M.M. R., Hossain, M.Y., Begum, M., Ahmed, Z.F., Ohtomi, J., Rahman, M.M., Alam, M.J., Islam, M.A. and Fulanda, B. 2008. Seasonal variations of Phytoplankton community structure and production in Related to Environmental factors of the Southwest coastal waters of Bangladesh. Journal of Fisheries and Aquatic Science, 3(2): 102-113. http://dx.doi.org/10.3923/ jfas.2008.102.113

Swingle, H.S. 1967. Relation of $\mathrm{pH}$ of pond water to shrimp suitability for fish culture. Proc.Pacific So. Congress. 9, 10:72-75.

Tasneem, S.L. 1998. Effects of periphyton of monoculture of Labeo rohita. M.S. thesis, Department of Fisheries Management, Bangladesh Agricultural University, Mymensingh, Bangladesh, 1-78.

Uddin, M.N. 2005. Study on duckweed (Lemna minor) use as feed for tilapia (GIFT strain $O$. riiloticus) in monoculture. M.S. thesis, Dept. of Fisheries Management, Faculty of Fisheries, Bangladesh Agricultural University, Mymensingh.

Wahab, M.A., Ahmed, Z.F., Islam, M.A. and Rahmatuilah, S.M. 1995. Effects of introduction of common carp, Cyprinus carpio (L.) on the pond ecology and growth offish in polyculrure, Aquacuil. $\quad$ Res., 26(9): 619-628. http://dx.doi.org/10.1111/j.1365-

2109.1995.tb00953.x

Zaman, M.N., Hossain, M. I., Rahman, M. S., and Islam, M. N., 2002. Effects of periphyton on monoculture of GIFT tilapia. J. bio-sci, 10:53-58. 